\title{
Methods to study the role of ectomycorrhizal fungi in forest carbon cycling 3 :
}

Quantification of the amount of carbon consumed by ectomycorrhizal fungi in a Japanese red pine forest

\section{Takami Satomura ${ }^{1 *}$, Yasushi Hashimoto², Akihiko Kinoshita ${ }^{1}$ and}

\section{Takao Hor ikoshi ${ }^{3}$}

'Graduate School of Biosphere Science, Hiroshima University, Japan

${ }^{2}$ Agro-Environmental Science, Obihiro University of Agriculture and Veterinary Medicine, Japan ${ }^{3}$ Graduate School of Integrated Arts and Sciences, Hiroshima University, Japan

\begin{abstract}
We estimated the role of mycorrhizal fungi quantitatively in a Japanese red pine (Pinus densiflora) forest. We directly estimated several parameters to calculate the amount of carbon consumed by mycorrhizal fungi, such as the biomass of fungi in ectomycorrhizal fine roots and fine root biomass, and drew other parameters from the literature. Our study site, a Japanese red pine forest, was characterized by a very small ectomycorrhizal fine root biomass (only $91.0 \mathrm{~g} \mathrm{~m}^{-2}$ ) and small fungal content in ectomycorrhizal fine roots $(2.2 \%)$ compared with the literature data. The ectomycorrhizal fine root biomass has a greater influence than the fungal content of ectomycorrhizal fine roots on the difference in fungal biomass in ectomycorrhizal fine roots among forests. The total biomass of ectomycorrhizal fungi in ectomycorrhizal fine roots and in soil was estimated to be only $10.0 \mathrm{~g} \mathrm{~m}^{-2}$. However, the total amount of carbon consumed by the production-death decomposition cycle of ectomycorrhizal fungi was estimated to be $117.0 \mathrm{~g} \mathrm{C} \mathrm{m}^{-2}$ year $^{-1}$, which corresponds to about $24 \%$ of carbon release from soil as soil respiration. Our estimation reconfirmed the importance of ectomycorrhizal fungi in forest carbon cycling. The carbon consumed by ectomycorrhizal fungi is not negligible, even in a stand having a very small biomass of ectomycorrhizal fungi.
\end{abstract}

Keywords: ergosterol, fine root, fungal biomass, mesh bag method, turnover

森林の炭素循環における外生菌根菌の役割を研究する手法 3 ：アカマツ林における外生菌根菌 に消費される炭素量の定量化の試み: 里村 多香美(広島大学大学院生物圈科学研究科), 橋本 靖 (帯広畜産大学環境総合科学講座), 木下 晃彦 (広島大学大学院生物圈科学研究科), 堀越 孝 雄 (広島大学大学院総合科学研究科)

要旨: 生態系の炭素循環における菌類の役割の重要性が認識されているにも関わらず, 野外条件下で 菌根菌に分配される炭素量の推定值は数えるほどしか報告されていない。生態系の炭素循環における菌類 の役割について定量的な值を用いて議論するため, アカマツ林で外生菌根菌に分配される炭素量を概推し た。直接得られなかった土壌中の外生菌根菌バイオマス, 細根（菌根を含む）と外生菌根菌のターンオー バーの值は, 文献值を参照した。その結果, アカマツ林の外生菌根菌のバイオマスの総量はわずか $10.0 \mathrm{~g}$ $\mathrm{m}^{-2}$ であると推定され，細根のバイオマスが少ないことが大きく影響していると考えられた。この林分で は菌根菌の生成と枯死サイクルによって年間に消費される炭素は $117.0 \mathrm{~g} \mathrm{C} \mathrm{m}^{-2} \mathrm{year}^{-1}$ と推定され，土壤か らの炭素の放出の約 $24 \%$ に相当した。アカマツ林は細根のバイオマス, 細根中の菌類含有量, 外生菌根菌 のバイオマスが共に文献值よりも非常に低いという特徵があった。森林タイプ間の外生菌根菌のバイオマ スの違いに大きく影響を及ぼしているのは, 細根中の菌類含有量の差異よりも細根のバイオマスの差異で あった。外生菌根菌のバイオマスが小さい森林においても, 菌根菌の生成・枯死サイクルによって消費さ れる炭素量は無視できないことが改めて確認された。

キーワード : エルゴステロール，細根，菌類バイオマス，メッシュバック法，ターンオーバー

\section{Introduction}

We detailed methods to study the role of ectomycorrhizal fungi in forest carbon cycling in previous papers in this series (Satomura et al., 2006a, 2006b). The biomass of fungi in ectomycorrhizal fine roots (plant-fungal interface),

*造絡先 Field Science Center fot the Northern Bioshere, Hokkaido University, Nishi 9-chime, Kita 9, Kita-ku, Sapporo 060-0809, Japan Tel: +81-(0) 11-706-3653 Fax: +81-(0) 11-706-3450 E-mail: takami_satomura@ybb. ne. jp 
as well as the biomass of ectomycorrhizal fungi in soil (called external mycelium; soil-fungal interface), the biomass of fungal tissues such as fruiting bodies and sclerotia, and their turnover are needed in order to quantify the role of ectomycorrhizal fungi in forest carbon cycling (for details see Satomura et al., 2006a). The importance of mycorrhizal fungi in terrestrial ecosystem carbon dynamics is widely recognized, but reports concerning the stand-level quantitative estimation of their role are limited. Investigations for improving the methodology are necessary. Pioneer studies to estimate the total amount of carbon consumed by ectomycorrhizal fungi (e.g. Finlay and Söderström, 1992; Wallander et al., 2001) gave valuable estimates for modeling carbon cycling in forests at the local and global scale, even though the estimates are rough. In Asian forests, however, no one has attempted to estimate it.

In this article, we compare the biomass and fungal contents of ectomycorrhizal fine roots between forests using literature data. Based on our data and assumptions in pioneering studies, we report the first estimate of the amount of carbon consumed by ectomycorrhizal fungi in an Asian forest.

\section{Variation in fungal biomass in ectomycorrhizal fine roots among forests}

Few attempts have been made to quantify the role of ectomycorrhizal fungi in forest carbon dynamics. In stand-level estimates, the biomasses of ectomycorrhizal fungi in fine roots differ among forest types (Table 1). The highest value (1000.9 g $\mathrm{m}^{-2}$ ground area) was obtained from a Pseudotsuga menziesii forest (Fogel and Hunt, 1979), and the lowest value $\left(2.0 \mathrm{~g} \mathrm{~m}^{-2}\right)$ in a Pinus densiffora forest (Satomura et al., 2003). The fungal contents of ectomycorrhizal roots and the ectomycorrhizal fine root biomass, two factors used to calculate the biomass of fungi in ectomycorrhizal fine roots, were much higher in the $P$. menziesii forest than in the $P$. densiffora forest (Table 1). Judging from the results in Table 1, the ectomycorrhizal fine root biomass has a stronger effect than fungal content of ectomycorrhizal fine roots on the difference in fungal biomass in ectomycorrhizal fine roots. The fungal content of ectomycorrhizal fine roots in the $P$. menziesii forest (40\%) was an order of magnitude greater than that in the $P$. densiflora forest $(2.2 \%)$, while the ectomycorrhizal fine root biomass in the $P$. menziesii forest $\left(2502.3 \mathrm{~g} \mathrm{~m}^{-2}\right)$ was two orders of magnitude greater than that in the $P$. densiffora forest $\left(91.0 \mathrm{~g} \mathrm{~m}^{-2}\right)$. Fine root biomass (all types of

Table 1 Variations in the biomass and content of root components among the sites studied in the literature.

\begin{tabular}{|c|c|c|c|c|c|}
\hline \multirow{2}{*}{ Parameters } & \multirow{2}{*}{$\begin{array}{c}\text { Pinus densifiora } \\
\text { forest }\end{array}$} & \multirow{2}{*}{$\begin{array}{l}\text { Picea abies } \\
\text { forest }\end{array}$} & \multicolumn{2}{|c|}{ Abies amabilis forest } & \multirow{2}{*}{$\begin{array}{l}\text { Pseudotsuga } \\
\text { menziesii forest }\end{array}$} \\
\hline & & & 23-year-old & 180-year-old & \\
\hline Climate & $\begin{array}{l}\text { Warm-temperate } \\
\text { zone }\end{array}$ & Boreal zone & $\begin{array}{l}\text { Cool-temperate } \\
\text { zone }\end{array}$ & $\begin{array}{l}\text { Cool-temperate } \\
\text { zone }\end{array}$ & $\begin{array}{l}\text { Cool-temperate } \\
\text { zone }\end{array}$ \\
\hline Forest type & $\begin{array}{c}\text { Needieleaf } \\
\text { evergreen forest }\end{array}$ & $\begin{array}{c}\text { Needleleaf } \\
\text { evergreen forest }\end{array}$ & $\begin{array}{c}\text { Needieleaf } \\
\text { evergreen forest }\end{array}$ & $\begin{array}{c}\text { Needieleaf } \\
\text { evergreen forest }\end{array}$ & $\begin{array}{c}\text { Needleleaf } \\
\text { evergreen forest }\end{array}$ \\
\hline Total root biomass $\left(\mathrm{g} \mathrm{m}^{-2}\right)$ & 3932.0 & - & 2369.0 & 14067.0 & 7431.2 \\
\hline Ectomycormizal fine root biomass $\left(\mathrm{g} \mathrm{m}^{-2}\right)$ & 91.0 & 560.0 & 113.0 & 185.0 & 2502.3 \\
\hline (Non-mycorthizal fine root biomass $\left(\mathrm{g} \mathrm{m}^{-2}\right)$ ) & - & - & (839.0) & (1441.0) & - \\
\hline Ectomycormizal fine root / total root (\%) & 2 & - & 5 & 1 & 34 \\
\hline Ergosterol content of ectomycorrhizal fine root ( $\mu g g^{-1}$ root $\left.d w\right)$ & $43.1-321.0$ & 166.0 & - & - & - \\
\hline Total amount of ergosterol in ergosterol fine root $\left(\mathrm{mg} \mathrm{m}^{-2}\right)$ & 8.2 & 93.0 & - & - & - \\
\hline Fungal biomass in ectomycorrthizal fine root $\left(\mathrm{g} \mathrm{m}^{-2}\right)$ & 2.0 & 15.1 & 68.0 & 111.0 & 1000.9 \\
\hline Fungal content of fine root (\%) & 2.2 & 2.9 & 40 & 40 & 40 \\
\hline $\begin{array}{l}\text { Method to obtain the fungal biomass and fungal content } \\
\text { in ectomycornizal fine roots (conversion factor) }\end{array}$ & $\begin{array}{l}\text { Ergosterol } \\
\text { method (4.10) }\end{array}$ & $\begin{array}{l}\text { Ergosterol } \\
\text { method (5.7) }\end{array}$ & $\begin{array}{l}\text { Root section } \\
\text { image analysis }\end{array}$ & $\begin{array}{l}\text { Root section } \\
\text { image analysis }\end{array}$ & $\begin{array}{l}\text { Dissection } \\
\text { method }\end{array}$ \\
\hline Reference & $\begin{array}{l}\text { Satomura et al. } \\
\text { (2003) }\end{array}$ & $\begin{array}{l}\text { Kárén and } \\
\text { Nylund (1996) }\end{array}$ & $\begin{array}{l}\text { Vogt et al. } \\
\text { (1982) }\end{array}$ & $\begin{array}{l}\text { Vogt et al. } \\
\text { (1982) }\end{array}$ & $\begin{array}{l}\text { Fogel and Hunt } \\
\text { (1979) }\end{array}$ \\
\hline
\end{tabular}


fine roots, including ectomycorrhizal fine roots and arbuscular mycorrhizal fine roots) tends to be smaller in Japanese forests dominated by the genus Pinus or Larix than in European and North American forests (Noguchi, personal communication). In Abies amabilis forests, the biomass of fungi in ectomycorrhizal fine roots, the fungal content of ectomycorrhizal roots, and ectomycorrhizal fine root biomass showed intermediate values (Vogt et al., 1982; Table 1). The values in a Picea abies forest (Kårén and Nylund, 1996) were rather close to the values in a $P$. densiffora forest (Table 1).

\section{Biomass of ectomycorrhizal fungi in soil}

Wallander et al. $(2001,2004)$ reported a pioneering stand-level estimation of the biomass of ectomycorrhizal fungi in soil using ergosterol analysis. Ergosterol is a common sterol in higher fungi such as the Ascomycetes and Basidiomycetes (Weete and Gandhi, 1996), and an ergosterol analysis of a soil sample reveals all functional types of fungi (e.g., heterotrophic, ectomycorrhizal) by measuring the total amount of ergosterol derived from all types of fungi. Wallander et al. (2001) separated out the ectomycorrhizal fungi by putting nutrient-poor sandy soil into mesh bags and incubating them in situ in soil from a $P$. abies forest on the assumption that the mycelia of the mycorrhizal fungi alone can penetrate into the soil in the mesh bags (the carbon isotope ratio of the mycelia extracted from the mesh bags supported this assumption). After a time, they analyzed the ergosterol content of the incubated sandy soil. The biomass of ectomycorrhizal fungi in the soil was about four times that in the fine roots. In other words, a large proportion of the biomass of ectomycorrhizal fungi (about $80 \%$ ) existed in the soil in the form of external mycelia. This value was within the range of the proportion of external mycelium to total fungal biomass in ectomycorrhizal fine roots and in soil (2-87\%) reported from laboratory experiments (Colpaert et al., 1992; Wallander and Nylund, 1992; Ekblad et al., 1995).

\section{How much do mycorrhizal fung i contribute to forest carbon dynamics?}

How much of a plant's fixed carbon is consumed by its fungal partner (mycorrhizal fungi)? We attempted to estimate the value in a $P$. densiflora forest (Satomura et al., 2003), making the following assumptions (Table 2): (i) turnover of fine roots $\left(0-2 \mathrm{~mm}\right.$ in diameter) is 0.8 year $^{-1}$ (Gill and Jackson, 2000), (ii) the biomass of ectomycorrhizal fungi in soil is four times that in mycorrhizal fine roots (Wallander et al., 2001), (iii) the turnover time of mycelia is 1 week during the 6-month growing season for ectomycorrhizal fungi (turnover is 26 year $^{-1}$ ) (Finlay and Söderström, 1992), and (iv) carbon content is $45 \%$ in both fine roots and the mycelia of mycorrhizal fungi. Based on these assumptions, we estimated the total biomass of fungi in ectomycorrhizal fine roots and soil to be only $10.0 \mathrm{~g} \mathrm{~m}^{-2}$ (Table 2 ). The productions of plant tissue in ectomycorrhizal fine roots, fungi in ectomycorrhizal fine roots, and ectomycorrhizal fungi in soil are estimated to be $71.2,52.0$, and $208.0 \mathrm{~g} \mathrm{~m}^{-2}$ year ${ }^{-1}$, respectively (Table 2). The amounts of carbon consumed by fine roots, ectomycorrhizal fungi in fine roots, and ectomycorrhizal fungi in soil are estimated to be $32.0,23.4$, and $93.6 \mathrm{~g} \mathrm{C} \mathrm{m}^{-2}$ year $^{-1}$, respectively (Table 2). The total amount of carbon consumed by the ectomycorrhizal fungi in a year $\left(117.0 \mathrm{~g} \mathrm{C} \mathrm{m}^{-2}\right.$ year ${ }^{-1}$ ) corresponds to about $24 \%$ of the annual carbon emission from soils (soil respiration) in a $P$. densiffora forest $\left(487.0 \mathrm{~g} \mathrm{C} \mathrm{m}^{-2}\right.$ year $^{-1}$ ) (Nakane et al., 1984). The study forest, a $P$. densiffora forest, is characterized by a very small biomass of ectomycorrhizal fine roots and their fungal partners (91.0 and $10.0 \mathrm{~g} \mathrm{~m}^{-2}$, respectively), compared with the total biomass of the belowground parts of plants

Table 2 Values in the calculations of carbon consumed by ectomycorrhizal fine roots and ectomycorrhizal fung $i$ in a Japanese red pine forest.

\begin{tabular}{|c|c|c|c|c|c|}
\hline Component & $\begin{array}{c}\text { Biomass } \\
\text { (g DW m }{ }^{-2} \text { ground area) }\end{array}$ & $\begin{array}{l}\text { Turnover } \\
\left(\text { year }^{-1}\right)\end{array}$ & $\begin{array}{c}\text { Production } \\
\text { (g DW m } \text { ground area year }^{-1} \text { ) }\end{array}$ & $\begin{array}{l}\text { Carbon content of } \\
\text { each parameter } \\
\text { ( } \% \text { biomass) }\end{array}$ & $\begin{array}{l}\text { Consumed carbon } \\
\left(\mathrm{g} \mathrm{C} \mathrm{m}^{-2} \text { ground area) }\right.\end{array}$ \\
\hline $\begin{array}{l}\text { Ectomycorrhizal fine roots } \\
\text { Plant tissue in ectomycomizal fine roots } \\
\text { Fungi in ectomycormizal fine roots } \\
\text { Ectomycorrhizal fungi in soil }\end{array}$ & $\begin{array}{c}91.0 \\
89.0 \\
2.0 \\
8.0\end{array}$ & $\begin{array}{l}0.8 \\
0.8 \\
26 \\
26\end{array}$ & $\begin{array}{c}123.2 \\
71.2 \\
52.0 \\
208.0\end{array}$ & $\begin{array}{l}45 \\
45 \\
45 \\
45\end{array}$ & $\begin{array}{l}55.4 \\
32.0 \\
23.4 \\
93.6\end{array}$ \\
\hline Ectomycorrhizal fungi total & 10.0 & & 260.0 & & 117.0 \\
\hline
\end{tabular}


at the study site (3932.0 $\mathrm{g} \mathrm{m}^{-2}$; Table 1; Satomura et al., 2003). However, the estimated productions of ectomycorrhizal fine roots and their fungal partners are considerable, reconfirming their importance in forest carbon dynamics. Neglecting the turnover of carbon through mycorrhizal fungi would significantly affect estimates of carbon dynamics in a forest ecosystem.

\section{Further considerations}

To quantitatively evaluate the role of ectomycorrhizae in carbon dynamics, it is necessary to determine not only the biomass but also the turnover of ectomycorrhizal fungi. But little is known about turnover. Data are also needed on the carbon content of mycelia and fruiting body production of ectomycorrhizal fungal species. Normally, fungal fruiting body production has been evaluated in Japan as the number of fruiting bodies (e.g., Shimono, 1988; Fujita, 1989). However, to quantify the carbon consumed by the production of fruiting bodies by ectomycorrhizal fungi, mass-based (weight-based) data are needed (Vogt et al., 1992).

Mycorrhizal fungi connect plant individuals and even species through the external mycelia in the soil (Simard et al., 2002; Simard and Durall, 2004). In some cases, the carbon fixed by one plant appears to be allocated to other plants through this hyphal network (e.g., Miller and Allen, 1992; Leake, 1994, 2004; Simard et al., 2002). This complicates the analysis of carbon movement in the soil. Further studies of carbon movement through plant-fungal-plant combinations are needed.

Many questions remain about the role of ectomycorrhizal fungi in forest carbon dynamics. Much more quantitative data collected in various types of forest under diverse environments is needed to answer questions about the role of mycorrhizal fungi in forest carbon dynamics. Many methodological problems must be solved to obtain all the required data.

\section{Acknow ledgements}

We are grateful to Dr. Takayuki Nakatsubo of Hiroshima University for his advice on this manuscript. We also thank Ms. Keiko Tanaka-Fujiyoshi of Hiroshima University for her help in the literature search. This study was partly supported by a Grant-in Aid from the Japan
Society for the Promotion of Science (no. 16570018).

\section{Literature cited}

Colpaert, J.V., van Assche, J.A., Lujtens, K. 1992. The growth of extrametrical mycelium of ectomycorrhizal fungi and the growth response of Pinus sylvestris seedlings. New Phytol. 120: 127-135.

Ekblad, A., Wallander, H., Carlsson, R., Huss-Danell, K. 1995. Fungal biomass in roots and extrametrical mycelium in relation to macronutrients and plant biomass of ectomycorrhizal Pinus sylvestris and Alnus incana. New Phytol. 131: 443-451.

Finlay, R., Söderström, B. 1992. Mycorrhiza and carbon flow to the soil. In: Allen, M.F. (ed) Mycorrhizal Functioning. Chapman \& Hall, New York, pp. 134-160.

Fogel, R., Hunt, G.. 1979. Fungal and arboreal biomass in western Oregon Douglas-fir ecosystem: distribution patterns and turnover. Can. J For. Res. 9: 245-256.

Fujita, H. 1989. Succession of higher fungi in a forest of Pinus densiffora. Trans. Mycol. Soc. Jpn. 30: 125-147.

Gill, R.A., Jackson, R.B. 2000. Global patterns of root turnover for terrestrial ecosystems. New Phytol. 147: 13-31.

Kårén, O., Nylund, J.-E. 1996. Effects of $\mathrm{N}$-free fertilization on ectomycorrhiza community structure in Norway spruce stands in Southern Sweden. Plant Soil 181: 295-305.

Leake, J.R. 1994. The biology of myco-heterotrophi ('saprophytic') plant. New Phytol. 127: 171-216.

Leake, J.R. 2004. Myco-heterotroph/epiparasitic plant interactions with ectomycorrhizal and arbuscular mycorrhizal fungi. Current Opinion in Plant Biol. 7: 422-428.

Miller, S.L., Allen, E.B. 1992. Mycorrhizae, nutrient translocation, and interactions between plants. In: Allen, M.F. (ed) Mycorrhizal Functioning. Chapman and Hall, London, pp. 301-354.

Nakane, K., Tsubota, H., Yamamoto, M. 1984. Cycling of soil carbon in a Japanese red pine forest $\mathrm{I}$. Before a clear-felling. Bot. Mag. Tokyo 97: 39-60.

Satomura, T., Nakatsubo, T., Horikoshi, T. 2003. Estimation of the biomass of fine roots and mycorrhizal fungi: a case study in a Japanese red pine (Pinus densiflora) stand. J For. Res. 8: 221-225.

Satomura, T., Hashimoto, Y., Kinoshita, A., Horikoshi, T. 2006a. Methods to study the role of ectomycorrhizal fungi in forest carbon cycling 1: 
Introduction to the direct methods to quantify the fungal content in ectomycorrhizal fine roots. Root Res. 15: 119-124.

Satomura, T., Hashimoto, Y., Kinoshita, A., Horikoshi, T. 2006b. Methods to study the role of ectomycorrhizal fungi in forest carbon cycling 2: Ergosterol analysis method to quantify the fungal content in ectomycorrhizal fine root. Root Res. 15: 155-159.

Shimono, Y. 1988. Effects of climatic conditions on the fruiting of Russula species in a Castanopsis cuspidata forest in Kyoto. Trans. Mycol. Soc. Jpn. 29: 73-84 (in Japanese with English summary).

Simard, S.W., Durall, D.M. 2004. Mycorrhizal networks: a review of their extent, function, and importance. Can. J Bot. 82: 1140-1165.

Simard, S.W., Jones, M.D., Durall, D.M. 2002. Carbon and nutrient fluxes within and between mycorrhizal plants. In: Van der Heijden, M.G.A., Sanders, I. (eds) Mycorrhizal Ecology. Springer, Berlin, pp. 33-74.

Vogt, K.A., Grier, C.C., Meier, C.E., Edmonds, R.L. 1982. Mycorrhizal role in net primary production and nutrient cycling in Abies amabilis ecosystems in western Washington. Ecology 63: 370-380.
Vogt, K.A., Bloomfield, J., Ammirati, J.F., Ammirati, S.R. 1992. Sporocarp production by Basidiomycetes, with emphasis on forest ecosystems. In: Carroll, G.C., Wicklow, D.T. (eds) The Fungal Community: Its Organization and Role in the Ecosystem, Second edition. Marcel Dekker, Inc., New York, pp. 563-581.

Wallander, H., Nylund, J.-E. 1992. Effects of excess nitrogen and phosphorus starvation on the extramatrical mycelium of ectomycorrhizas of Pinus sylvestris L. New Phytol. 120: 495-503.

Wallander, H., Nilsson, L.O., Hagerberg, D., Bååth, E. 2001. Estimation of the biomass and seasonal growth of external mycelium of ectomycorrhizal fungi in the field. New Phytol. 151: 753-760.

Wallander, H., Göransson, H., Rosengren, U. 2004. Production, standing biomass and natural abundance of ${ }^{15} \mathrm{~N}$ and ${ }^{13} \mathrm{C}$ in ectomycorrhizal mycelia collected at different soil depths in two forest types. Oecologia 139: 89-97.

Weete, J.D., Gandhi, S.R. 1996. Biochemistry and molecular biology of fungal sterols. In: Brambl. R.B., Earzluf, G.A. (eds) The Mycota III. Springer-Verlag, Berlin, pp. 421-438. 